\title{
Repetitions, Their Phonetic Features And Functions In Kurmanji Kurdish
}

\author{
Aveen Mohammed Hasan, PhD \\ Baydaa Mohammed Saeed Mustafa, MA
}

University of Zakho, Kurdistan-Region, Iraq

doi: 10.19044/esj.2016.v12n20p250 URL:http://dx.doi.org/10.19044/esj.2016.v12n20p250

\begin{abstract}
The study deals with the analysis of repetitions, their phonetic structures and functions as demonstrated in the organisation of talk-ininteraction in Kurdish. The repetitions are described as complex phonetic objects whose design has received no previous attention and are neglected by the scholars in the fields of discourse and conversation analysis studies in Kurdish. The main aims of the study are to identify the phonetic characteristics of repetitions in Kurdish, their functions and the relationship between differences in the phonetic features and their functions in speech. The study integrates the methodology of conversation analysis and impressionistic and instrumental phonetics to show how repetitions in a conversation are managed by the participants. The data used in this study comes from different types of natural speech, namely, face to face conversations, radio-phone-ins of Northern Kurdish. 27 cases of self repetitions have been analysed and they are lexical, phrasal and clausal with a range of syntactic forms. The study contributes to the theoretical issues of the prosody-pragmatics interface and participants' understanding of naturally occurring discourse. It is hoped that such a study may contribute to language and information processing by providing a detailed analysis of patterns and functions of repetition in social interaction.
\end{abstract}

Keywords: Repetitions, talk-in-interaction, Kurdish discourse, Kurdish repetitions, conversation analysis

\section{Introduction}

Repetitions are defined as the reoccurrence of patterns of phonemes, words, phrases, sentences or larger chunks of discourse (Tannen, 2007). Different types of repetitions are distinguished in the literature. Tannen (2007) distinguished synchronic and diachronic repetitions. Synchronic repetition involves the restatement of words and phrases in the same 
discourse, while diachronic repetition is their recurrence in discourse at a later time. In terms of sequential organisations and functions, Hsieh (2011) recognised two types of repetitions: self-repeats and other-repeats. Selfrepeats are defined as a set of consecutive repeats with or without the interference from the other party. Other repeats are used to confirm with the speaker's social interactant.

Repetitions received little research in English (Curl, 2002, Curl, Local \& Walker, 2006) and no previous investigation in Kurdish to date. This study contributes to increase our knowledge of this particular activity in conversation and it is the first to describe the phonetic and interactional structure of repetitions in conversation and addresses this gap in Kurdish linguistic studies. In talk-in-interaction, it is found that the same lexical item (or string of lexical items) uttered by the same speaker may have rather different phonetic shapes in different contexts (Curl, Local \& Walker, 2006). This study will concentrate on the phonetic design of repetitions, their functions and the interrelationship of phonetic structure and repetitions as particular activities in conversation managed and oriented by the participants themselves. It contributes to a growing body of work which shows how systematically produced clusters of phonetic events are manipulated and responded to in both shaping and interpreting talk in natural conversation (Curl, 2002, Curl, Local \& Walker, 2006). This study will deal with synchronic self-repetitions in Kurdish, that is the self-repetitions that occur in the same discourse with or without a reactive turn form the other party and will focus on some phonetic features namely, duration, loudness, pitch contour, pitch ranging, prominence and phrasing. It emphasises the importance of combining the phonetic and interactional analysis and demonstrates that the study of phonetic structure of repetitions can improve our understanding of the actions that they are used to accomplish.

The paper is structured as follows: in section 2, a review of previous studies on repetitions is presented. Section 3 details the methodological issues used in the data collection and analysis. In section 4, we present the main results arrived at throughout the data analysis. It introduces the phonetic characteristics of repetitions: duration, pitch contour, loudness, prominence and phrasing and their main communicative functions are presented. The conclusions and implications of our analysis are discussed in section 5 .

\section{Previous studies on repetitions}

Repetitions have been studied from different perspectives: from phonetic level (Fowler \& Housum, 1987; Fowler, 1988), conversation analysis (CA) methodology (Schegloff, 1996, Wong 2000) and from 
conversation and phonetic analysis methodologies (Curl, 2002; Curl, Local \& Walker, 2006).

Fowler and Housum (1987) compare the repetition of a word to its first production in a series of experiments. The study is based on a radio monolog. One type of analysis performed is the comparison of the duration of first and second mention of a word. The words are excised from the surrounding and measured. It is found that the second mention of a word is significantly shorter than the first mention. They suggest that by producing the second mention of a word differently, namely with a shorter duration, speakers alert hearers that this is the same entity as referred before. This study is based on data that comes from one-sided communicative setting, i.e. radio monolog, rather than using data from conversations and dialogs.

Therefore in a follow up study, Fowler (1988) presents an evidence for the importance of the communicative context. He conducted three experiments to test the effect of context on the durational shortening of the repeated words. The first experiment looked at shortnening in read word list and found that repeated words were not shorter than the first mentions of words. In the second experiment the subjects read a paragraph aloud and some durational shortening effects were observed. The third experiment examined the duration of new and old mentions of the same word in a spontaneous monolog compared to new and old mentions of the same word in a read speech. It is found that the durational shortening effect is greater for the spontaneous speech than for the read passage. Although this study has looked at various communicative contexts, little attention has been paid to the importance which the repetitions attribute to the communicative setting.

Using the CA framework, Schegloff (1996) deals with the ways in which a repeat is used to confirm another's understanding of what is previously said, a phenonmenon he describes as confirming an allusion, i.e. confirming both the content and the prior inexplicit conveyance of what has been said before. He adds that confirming by repeating is a relatively minor hue in the cultural, discursive and behavioural palette of commonplace interaction.

Following the same method, Wong (2000) describes repetitions in ordinary conversations as produced by native speakers of American English. She analyses those repetitions which a speaker produces the first and the second saying within the same turn with an inserted element coming between them. She discusses their position, composition and action. She adds that these forms of repetition are used as a storytelling technique by the speakers in the accomplishment of the action of resumption. A speaker starts a multiunit turn, does self-interruption by inserting a parenthetical remark that offers explanatory material or initiates repair and subsequently resumes the story. 
Curl (2002) investigates the interrelationship of phonetic structure and sequence organization in talk-in-interaction by integrating the methodology of CA and impressionistic and instrumental phonetics. The study examines the phonetic characteristics of repetitions in other-initiated repair sequences in American English, in which speakers repeat their immediately prior talk after prompting (e.g., what?; huh?). The results reveale a relationship between the phonetic details of the repetition and the trouble source turn it repairs. Curl adds that sequentially fitted trouble source turns are repaired with repetitions characterised by loudness, expanded pitch ranges, longer durations, and long-domain changes to the articulatory settings (compared to the trouble source turns), whereas, disjunct trouble source turns at the place in structure where they occur are repaired with repetitions that are less loud, have non-expanded pitch ranges, shorter durations, and no major differences in articulation when compared to the trouble source turns. This indicates that the systematic differences in the phonetic realization of repetition repairs co-occur with differences in the turn-taking properties and sequential relevance of the original utterance. It emphasizes the importance of combining attention to phonetic detail with sequential analysis to fully understand the orderliness in everyday talk-ininteraction.

Curl, Local and Walker (2006) have shown that the second parts of repetitions display particular phonetic characteristics which are interpreted with reference to the phonetic characteristics of the first part which include tempo, loudness as well as pitch. In their study, they concern with clausal repetitions that exhibit a range of syntactic forms. They adopt an approach that emphasises the necessity of exploring participants' understandings of pragmatic inferences in talk and attempts to prejudge as little as possible the relevance of phonetic (prosodic) parameters. They find that from a phonetic point of view speakers draw on a range of phonetic features and relationships between features which include tempo and loudness as well as pitch in designing these repetitions. From a pragmatic point of view, it reveals that these repetitions function to close sequences of talk.

Another study by Bard, Lowe and Altmann (1989) has analysed the effects of the discourse roles of repetitions on the intelligibility. The study is based on two experiments on words isolated from recorded dictations. It shows that the effect of repetition on intelligibility depends on the discourse roles of the token being compared. When the repetition adds no new information to the discourse, intelligibility falls with reptition, whereas when the repetition introduces a new discourse entity, intelligibility may rise with repetition.

Repetitions have been studied in other languages as well. Hsieh (2011) investigats repetitions, their types and functions in social interaction 
by examining data collected from Mandarin conversation in Taiwan, including face-to-face conversations, radio call-in programs and telephone conversations. He focuses on synchronic repetitions, i.e. the recurrence of words and phrases in the same discourse. Then he identifies two types of synchronic repetitons: self-repeats which are a set of consecutive repeats with or without the interference from the other party in the social interaction and other-repeats which are used by the speaker to agree with his/her social interactant. Then he discusses the main communicative functions of these types of repeats in conversations.

Following Curl, Local and Walker (2006), this study will analyse repetitions from the CA and phonetic analysis perspectives. CA mainly deals with explaining the way coherent and sequential organization in discourse is constructed and understood in order to identify systematic properties in talk (Levinson, 1983). The focus of the analysis is on participants' interpretation of the ongoing interaction which shape their following contribution to the discourse (Wooffitt, 2005). Consequently, context is the product of participants' actions and therefore locally produced in the given interaction. CA focuses on natural occurring talk and sequences and speaking turns within sequences are the primary units of analysis (Sidnell, 2010).

\section{Methodology}

This section presents the methods used in the data collection and analysis. First, the study database is described. Then details of the fragments transcription, preparation for analysis and the criteria for their selection are given. After that, the details of the phonetic parameters are presented.

\section{The data}

The study data is collected from two sources, namely, face to face conversations, and radio-phone-ins of NK Kurdish. The conversations contain a set of 10 recorded interviews with the native speakers of the NK which were recorded for a previous study on intonation. The researchers prepared a set of questions and the topics used for discussion are 'music' and 'travel'. The participants knew that they are being recorded but they were free as what to say. The participants aged between 20-30 and were recruited in Duhok. The recordings took place at Duhok University using PRAAT software program. As for the second source of the data, 6 radio-phone-ins programs were selected from the archives of Duhok radio, a local radio in Duhok area. Each program was about one hour and included an interview with a person which was interrupted by phone calls from other people who were participating and commenting on the topic of the program. The 
participants are recruited in Duhok and they are from different ages, genders and social classes.

Each pair of repetition and the surrounding context was extracted from the original file and saved as a separate WAV file using PRAAT. A collection of 27 cases of exact self repetitions were drawn from the data and used for this study. They are from different types: lexical (<nexêr $>$ (no)), phrasal (<di ḧeftiyêda> (in a week)) and clausal (<ez ḧejê nakem> (I don't like it.)) repetitions with a range of syntactic forms. Repetitions which contain additional items or have a lexical item omitted are left out of the analysis.

\section{Data analysis}

The data were listened to and the repetition pairs were identified by the ear. These pairs and the surrounding contexts were then transcribed by the authors according to the following conventions. The orthographic transcription was first carried out using the Latin Kurmanji writing system (Hasan, 2012) because it is very close to the English writing system. Throughout the paper, the translation of the examples are givn in rounded brackets. Following Curl (2002), other transcription conventions used include:

Then the phonetic analysis was done using PRAAT. First, the repetition pairs were identified in one tier and were selected for the phonetic measurements and comparison between the two repeated utterances. Then, each utterance was further segmented into words. Figure (1) illustrates the data segmentation of the sentence <em radkeyn> (we take them away.) and its repetition.

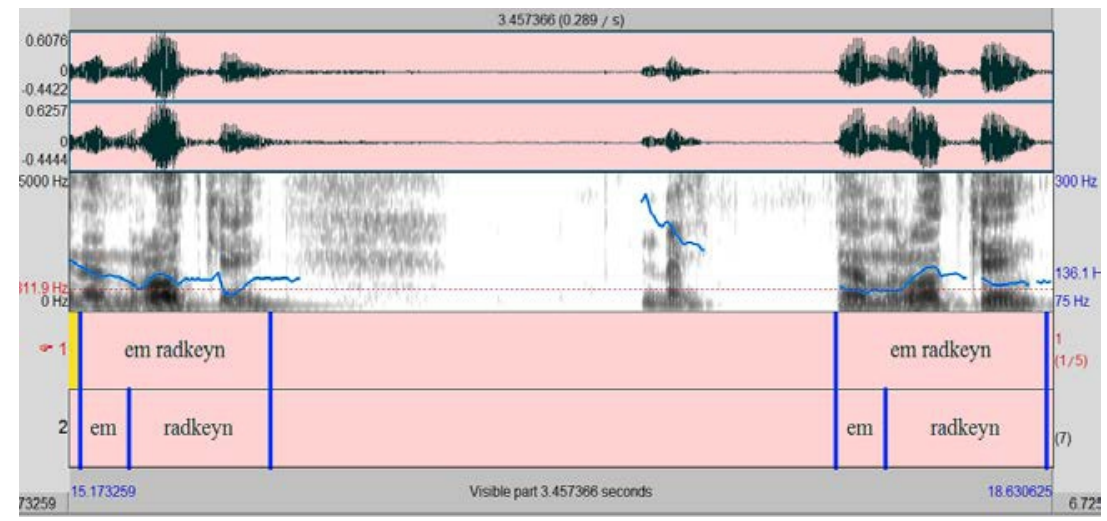

Figure 1: the segmentation of the sentence <em radkeyn> (we take them away.) and its repetition. 
After that, the phonetic measurements were carried using PRAAT functions. Four parameters were chosen: loudness, f0 contour, pitch range and duration which were found to vary systematically between the utterances (Curl, 2002). Loudness or intensity is defined as the measurement of the amount of disturbance that a sound wave causes to the surrounding air molecules (Laver, 1994). The intensity measurements were taken suing PRAAT in decibels (dB). The f0 contours and pitch range were also extracted using PRAAT functions. They were modelled by Hertz scale. The f0 trace of each repetition utterance was examined and the overall pitch range was measured by finding the maximum and minimum pitch level of each repetition utterance. The duration of each utterance was extracted by a PRAAT script and measured in milliseconds.

\section{Results}

This section presents the main results arrived at throughout the data analysis. The first section presents the durational characteristics of repetitions. The second section deals with pitch contour and pitch range characteristics. Sections three and four discuss the loudness and prominence and phrasing characteristics respectively. Finally, section five will present the main communicative functions of repetitions observed in the data.

\section{Duration characteristics}

Differences in the duration of the utterances first mention and their repetitions are shown in table 1 . The table shows that the majority of the repetitions have shorter durations than their first mentions (19 cases of the 27 examined samples) regardless of their functions. In the other 8 cases, it is observed that the duration of the repetition is longer than its first mention.

Table 1: duration measurements of the utterances in their first mention and in their repetitions

\begin{tabular}{|c|c|c|c|c|}
\hline & Utterance & $\begin{array}{c}\text { Duration of } \\
\text { the first } \\
\text { mention }\end{array}$ & $\begin{array}{c}\text { Duration of the } \\
\text { repetition }\end{array}$ & $\begin{array}{c}\text { Duration of } \\
\text { the third } \\
\text { mention }\end{array}$ \\
\hline $1-$ & di ḧheftiyêda (in a week) & 1.0946 & 1.0054 & \\
\hline $2-$ & $\begin{array}{c}\text { wekî tișt tu și çi xerîbdbî } \\
\text { (As a thing, what thing do you } \\
\text { miss) }\end{array}$ & 1.7159 & 1.6152 & \\
\hline $3-$ & bi șevê (at night) & 0.4424 & 0.3589 & \\
\hline $4-$ & ez hejê nakem (I don't like.) & 0.6892 & 0.6509 & \\
\hline $5-$ & Nexêr (no) & 0.623 & 0.3855 & \\
\hline $6-$ & $\begin{array}{c}\text { zekeriya e’bdula } \\
\text { (Zakeriya Abdullah) }\end{array}$ & 0.7762 & 0.7108 & \\
\hline $7-$ & deyka min (my mother) & 0.5272 & 0.5976 & \\
\hline $8-$ & her cihekê (any place) & 0.9228 & 1.0958 & \\
\hline $9-$ & parkên giștî (general parks) & 0.7727 & 0.8234 & \\
\hline
\end{tabular}




\begin{tabular}{|c|c|c|c|c|}
\hline $10-$ & Zawîte (Zawite) & 1.0235 & 0.6464 & \\
\hline $11-$ & eyub e’lî (Ayub Ali) & 0.5858 & 0.4971 & \\
\hline $12-$ & bes korka (just holes) & 0.6838 & 0.6531 & \\
\hline 13- & $\begin{array}{c}\text { em radkeyn } \\
\text { (we take them away) }\end{array}$ & 0.6663 & 0.7402 & \\
\hline 14- & $\begin{array}{c}\text { sebebê wê çiye } \\
\text { (what is the reason behind } \\
\text { that) }\end{array}$ & 1.0749 & 0.8522 & \\
\hline $15-$ & $\begin{array}{c}\text { zor supas bo te } \\
\text { (thank you very much) }\end{array}$ & 1.048 & 0.8741 & \\
\hline 16- & $\begin{array}{l}\text { me gazinde ser ḧukometê nîne } \\
\text { (we don't have any complaints } \\
\text { againt the government.) }\end{array}$ & 1.6616 & 1.4452 & \\
\hline 17- & geștîyar (tourist) & 0.7139 & 0.5531 & \\
\hline $18-$ & $\begin{array}{l}\text { peșnîyarek ya hey } \\
\text { (I have a suggestion) }\end{array}$ & 0.9478 & 0.945 & \\
\hline $19-$ & hizar silav (thousands regards) & 0.7251 & 0.5359 & \\
\hline $20-$ & $\begin{array}{l}\text { qonaxa avakirnê } \\
\text { (construction stage) }\end{array}$ & 0.9108 & 0.8704 & \\
\hline 21- & gelek (a lot) & 0.3307 & 0.396 & \\
\hline $22-$ & $\begin{array}{c}\text { taybet eger avîna ek layenî bît } \\
\text { (especially if it is a one side } \\
\text { love) }\end{array}$ & 1.9201 & 2.1478 & \\
\hline 23- & $\begin{array}{l}\text { ta șeva êk șembî } \\
\text { (till Sunday’s night) }\end{array}$ & 1.6568 & 1.3238 & 0.8923 \\
\hline $24-$ & $\begin{array}{c}\text { tu ji çi tirsiyay } \\
\text { (what were you afraid of?) }\end{array}$ & 0.7165 & 0.9118 & \\
\hline $25-$ & $\begin{array}{c}\text { tu têda jiyaye (did you live } \\
\text { in?) }\end{array}$ & 0.9176 & 0.8527 & \\
\hline $26-$ & $\begin{array}{l}\text { em dê çîne kurdistanê } \\
\text { (we will go to Kurdistan) }\end{array}$ & 1.4491 & 1.4012 & \\
\hline $27-$ & $\begin{array}{l}\text { da li yarîgeha xo ket } \\
\text { (they would play in their } \\
\text { ground.) }\end{array}$ & 1.3995 & 1.4726 & \\
\hline
\end{tabular}

This finding agrees with Fowler and Housum's (1987) and Curl, Local and Walker's (2006) results that the second parts of the repetitons are shorter in duration than their first parts.

Cases in which the duration of the repetition is longer than that of the first mention of an utterance are discussed below.

In < deyka min> (my mother) and <em radkeyn> (we take them away), the repetitions are longer than the first mentions as a means to give the speaker some time to think about what to say next. In $<$ deyka min $>$, the speaker is asked whom he will miss when he goes away from home. He answered <deyka min> then he repeats the phrase to give the reason why he selected my mother as the only person he will miss. The repetition is longer than the first mention as indicated in figure 2 and it is used to give the 
speaker some time to think of a reason. The speaker used a repetition to gain time rather than just a pause, or some filler word because it is his turn and he wants to keep it until he gives a reasonable answer.

1- A: demê tu ji mal dîrdkevî tu bara pitir și çi xerîbî yan și kê xerîbî $(0.4)$

(When you go away from the house, what or whom do you miss a lot?) min xireke.

B: çipênevêt deyka min (0.7) deyka min çunko [eeeeee] (0.5) jiyana

(Of course my mother..my mother because..she is all my life.)
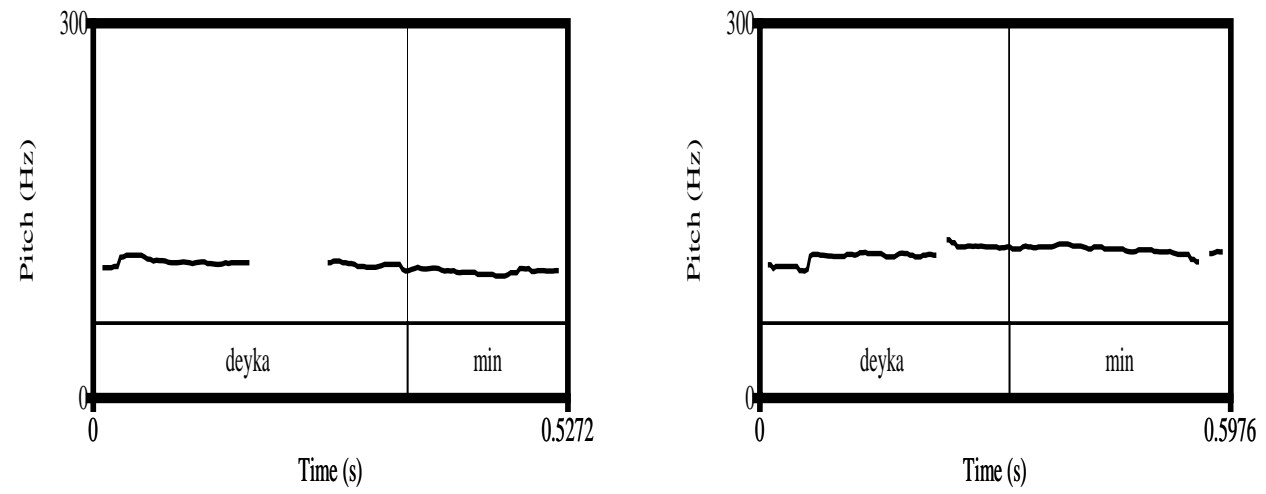

Figure 2: Duration comparison of the first mention of < deyka min $>$ (my mother) and its repetition

The figure also shows that there is a difference in the duration of the component words of this utterance. <deyka> is shorter in the repetition, while $<\min >$ is longer.

Similarly in <em radkeyn>, the repetition is longer than the first mention as indicated in figure 3 because the speaker is thinking about what to say next. So, he repeats to give himself more time for thinking.

2- A: hebuyne xelkî xo ţeșe danabin (.) erê hiker hat u danabin bê razemendîya hewe yan ya bajervanîyê, hewe çi heye digelda biken an çi pê rabun hene?

(Are there people who put ramps themselves? If they put them without your or the municipality consent, what are the procedures that are used to deal with them?)

B: xodê xelik wekî dbêjin e radbin bi wêji ew xitweye dhête kirnê (0.2) bes hindî

wekî me gutî em bzanîn em ewdîdkeyn em radkeyn (1). got informed

(Well people do that, it is a step that is done..but as we said if we 
about it we take them away.)

A: belê (yes.)

B: em radkeyn (eeeeeee) bu wê da neyn çi çi ew dê ţeșe dê danîte ber mala xo. bote

model hema her êk liber mala xo ţeșekê deynîtin.

(We take the away..in order that is does not become a habit and everyone puts a

ramp in front of his house.)
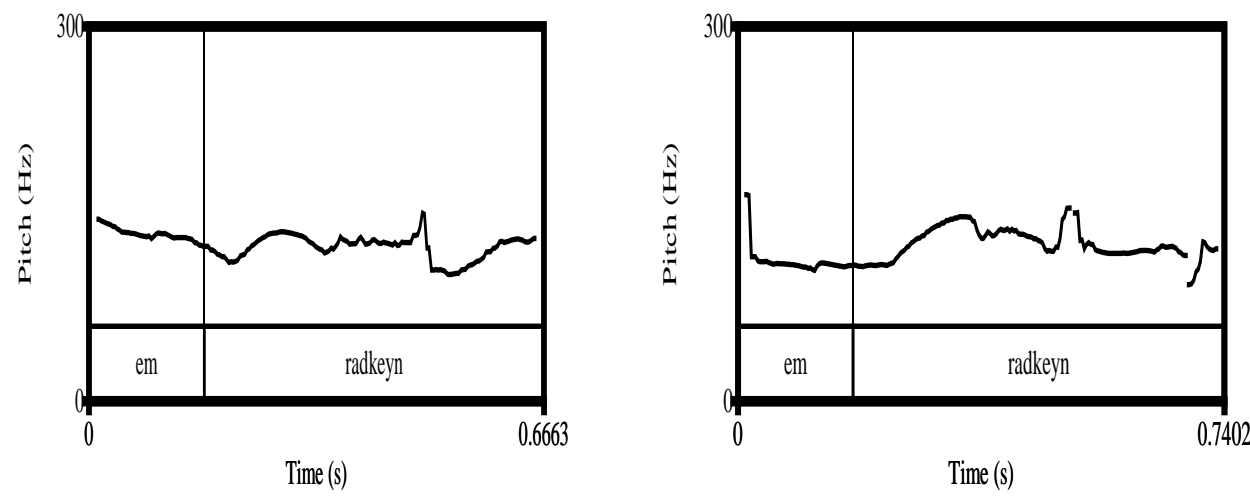

Figure 3: Duration comparison of <em radkeyn>and its repetition

Furthermore, the repetition can be longer than the first mention for the sake of emphasis. In the repetition <parkên giṣtîne> (public parks), the speaker is asked to tell about the nicest places to spend a holiday. The speaker answered that the nicest places are the public parks. Then he repeats public parks < parkên giștine> as the only places he thinks. The speaker has nothing to say more so he just repeated the answer for more emphasis.

3- A: bi hizra te xoṣtrîn cih bo burîna bihinvedana çine? eger kesek rojekê ji dervey welatî hat u pisyara te kir ka kij cih xoṣe bo bihinve[danê. tu dê çi] cih bo helbjêrî? (0.5)

(In your opinion, what are the best places to spend holidays? If one day a foreigner asked you about the best places to spend a holiday, which place will you choose?)

B:

[xoṣtrîn cih]

xoṣtrîn cih bo burîna bihinvedana parkên giștîne.(0.7)

(The best places to spend holidays are the public parks.)

A: belê (yes.)

B: parkên giștî her parkeka li e’ardekî bît.

(The public parks which are available.) 

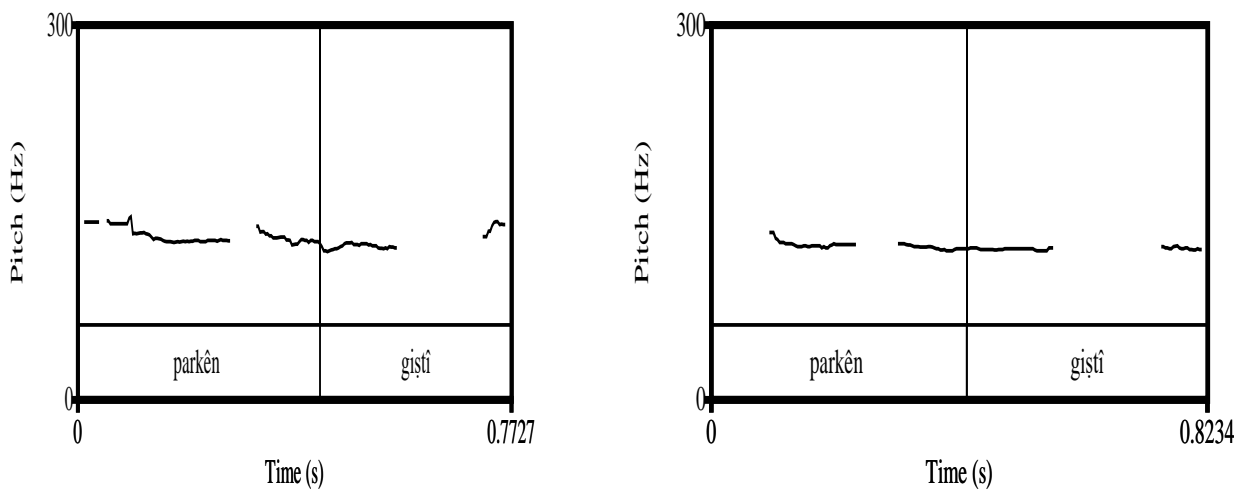

Figure 4: Duration comparison of <parkên giștîne> and its repetition

Another case in which the second repetition has longer duration is because of the deletion and production of some sound segments as it is found in <gelek> and <taybet eger avîna ek layenî bît>. In <gelek> (a lot), the repetition is done immediately after its first mention for the sake of emphasis. The first repetition is shorter because the word is uttered without the production of the $/ \mathrm{k} /$ sound at the end as shown in figure 5 .

4- B: evejî hh ee dvêt em dvê șarazabin (0) çunke em di qonaxeka avakirnêda (0) qonaxa avakirnê dê çewa peydabît hh qonaxa avakirnê (0.2) her kesek ji layê xove bitaybet (0.3) çunke ee ragehandin (0) sulta çarêye (0) wextê desthelata çarêbît hh dvêt ragehandinêda gele gelek eee (0) kesên xodan șiyan (0) kesên eee welat parez (0) bkevine kenala ragehandinê (0) da bṣ̂n peyameka drust bo vî welatî bo vî miletî bgehînin.

(This hhh we should be skillful with this.. because we are in a construction stage.. How is the construction stage found hh The construction stage.. every person especially by himself.. Because the media.. is the fourth authority.. When it is the fourth authority hh it is necessary that it should include a lot of ..professional people.. patriotic people.. in the media channels ..in order to be able to deliver a true message for this nation.)

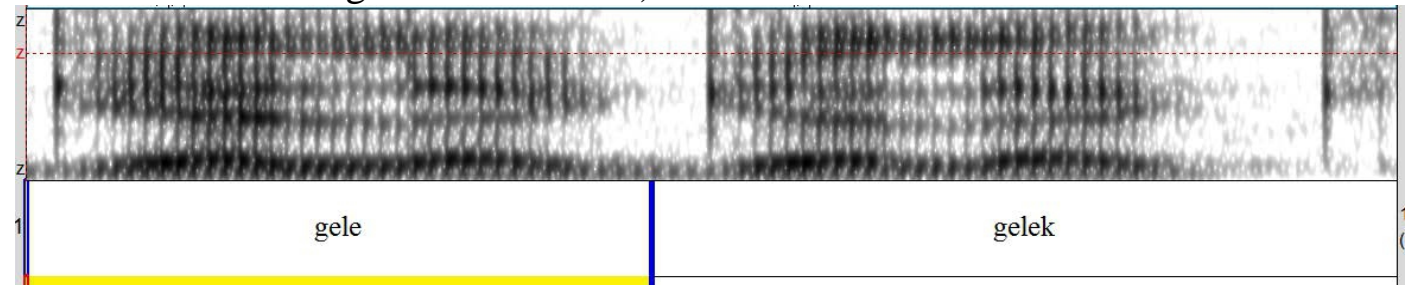

Figure 5: Spectrum comparison of <gelek> in its first and second mention 
In <taybet eger avîna ek layenî bît> (especially if it is a one side love), the second repetition is longer because of the production of $/ \mathrm{j} /$ sound in $<e k>$. The word $<e k>$ can be pronounced as $<e k>$ or as $<y e k>$. The first mention $<e k>$ is produced and in the second $<y e k>$ as illustrated in figure 6. The repetition is done because the hearer did not hear the utterance because of the overlap so he asked the speaker to repeat what she has just said by the rising intonation in $<$ belê $>$.

5- B: brastî ș̂lan (0.3) evînî bi dar u bera nekevîtin (0) avînî mirovî ti dzanî çilêdketin (0) avînî mirovî pîr dketin (0) mirovî dqehrînît u sere mirovî spî dketin (0.5) çedbît mirovî dîndket ne (0.5) u zêde zêde qeleqê ji bo mirovî çêdket u häala nefsîîi (0) ez bxo dbêjim bê lume (0.6)

(In fact Shilan..Love is very hard. Do you know what does it cause to a person? Love makes a person old. It makes a person sad and whiten his hair..It may make him crazy..or cause a lot of worry and a bad psychological condition to a person...I myself say no blames.

A: belê (0.3) (yes.)

B: [belê eger] (yes if..)

A: [taybet eger avîna ek layenî bît (0) yan ne (0.8)

(especially if it is a one side love. or not?)

B: belê (0.3) (yes)

A: taybet eger avîna yek layenî bît. (especially if it is a one side love.)
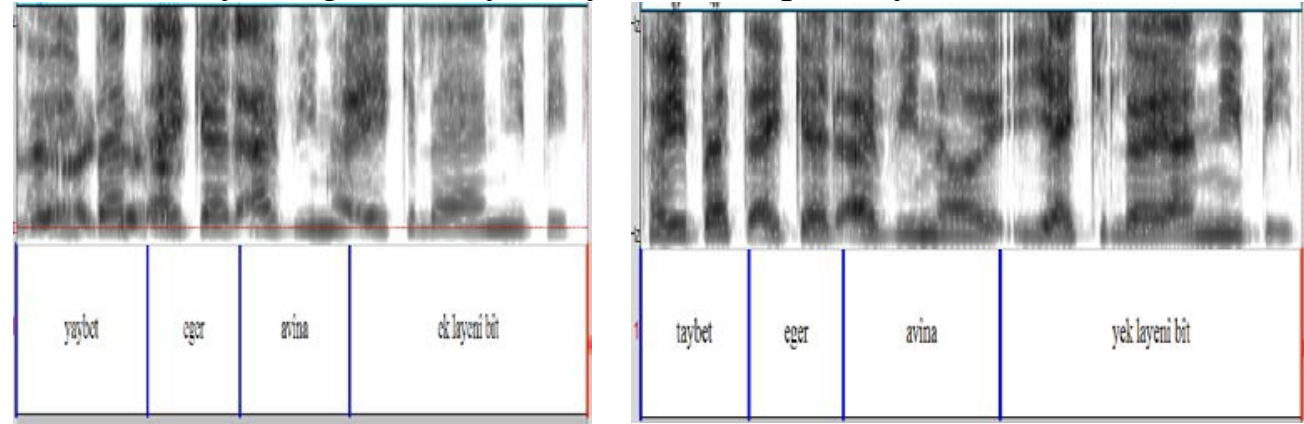

Figure 6: Spectrum comparison of < taybet eger avîna ek layenî bît $>$ in the first and second mention.

Furthermore, the differences in the duration of the first mention of an utterance and its repetition may be due to differences in the prominence structure of the utterance. For instance in:

6- A: tu ji çi tirsiyay menaf (0) bașe tu êk ji wan ḧalatayni (0) tu ji çi tirsiyay?

(What were you afraid of Menaf? You were one of these cases. What were you afraid of?) 
the repetition is longer than the first mention of $<t u$ ji çi tirsiyay $>$ (what were you afraid of?) because there are differences in the prominence. The speaker repeated the question for the sake of emphasis. In the first repetition the prominence is on the question word $<$ çi $>$ whereas in the repetition the prominence is on the question word and the word <tirsiyay $>$ as shown in figure 7 .
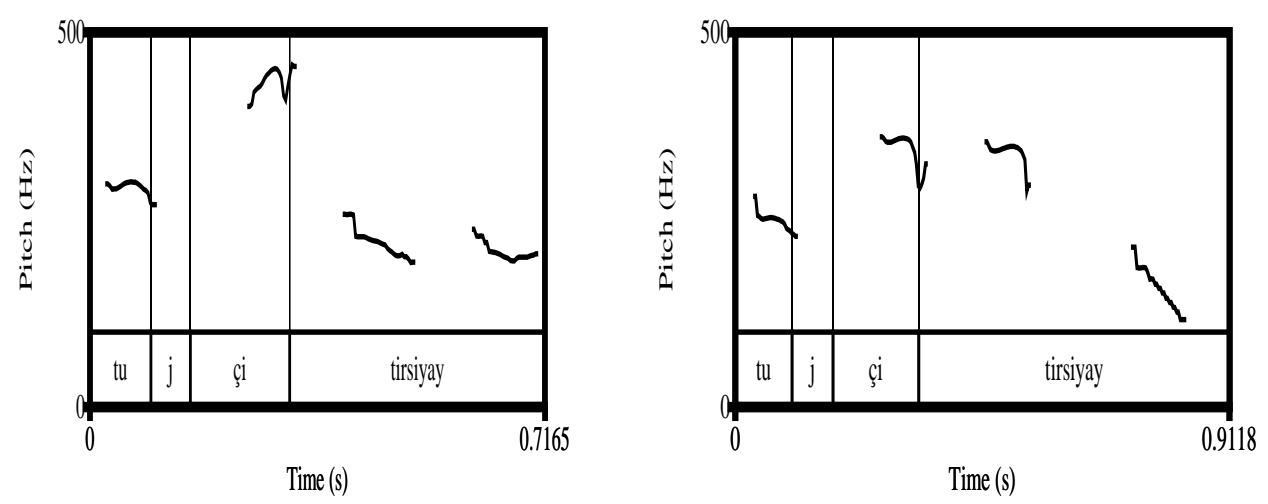

Figure 7: Prominence differences between the first mention and the repetition of $<$ tu ji çi tirsiyay>

Finally, the duration of the repetition is longer than that of the first mention because of hesitation and the insertion of hesitation fillers such as $<\mathrm{ee}>$. For instance, in the fragment 7 :

7- B: ez pîrozbahîya yana duhokê dikem bo derbazbuna wê li kasa îtih̆ada [eee] asyewî bo qonaxa dahatîda u (0.4) bes her bo yana duhok e'la alaqel wek hevba digel yana feyselî da piter (0.4) da (0) da yarya dahatî [ee] li ser kêșa (0.4) komê da li yarîgeha xo ket ez bêjim wekî min pê zanîn liser heyn (0.4) da li eee yarîgeha xo ket (0)

(I congratulate Duhok team for reaching the other stage in the United Asia Cup..but Duhok team had at least to equalise with Alfaisal team..so that in the coming match..it will be the first in the group and would play in its ground..I think as I know..it would play in its ground.)

The utterance <da li yarîgeha xo ket> (they would play in their ground.) is repeated for the sake of hesitation. The second repetition is longer because of the insertion of the hesitation marker <eee>. Figure 8 shows the duration differences between the first and second mention of the utterance $<$ da li yarîgeha xo ket>. 

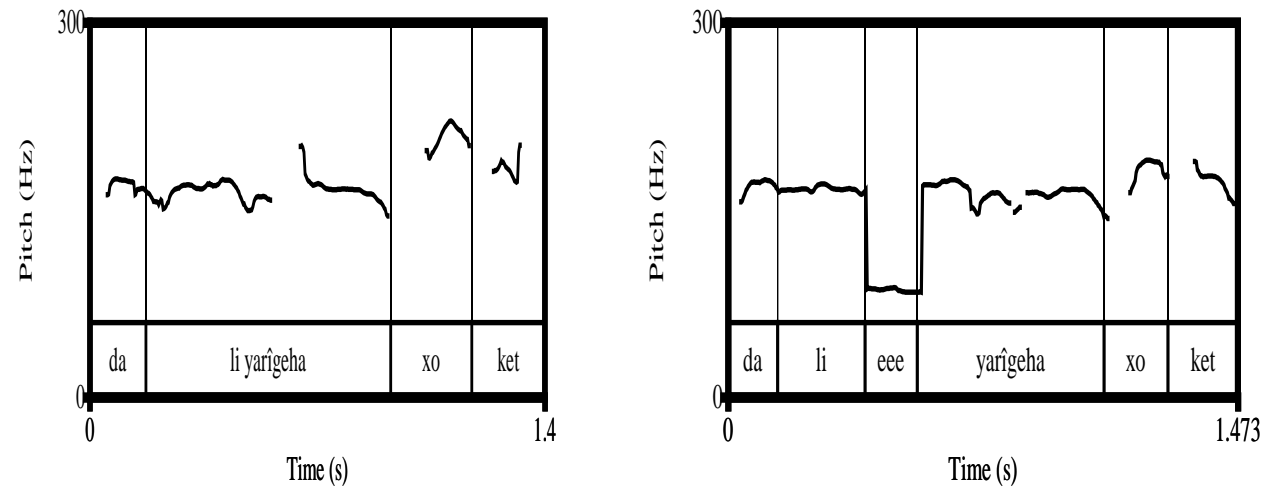

Figure 8: Duration differences between the first and second mention of the utterance $<$ da li yarîgeha xo ket>

Similarly, in the repetition <her cihekê> (any place), the speaker is asked to tell which place she visited is the nicest. It seems that she is not sure about what to say and has not formulated her answer so she uses repetition to show her hesitation. Besides, her speech is also full of pauses and filled pauses such as <eee $>$. The second repetition of $<$ her ciheke $>$ is longer that the first mention because the components of the utterance are interrupted by a short pause as indicated in figure 9 .

8- A: tu di șêy bêjiye me xoștrîn cih tu çuyê heta nuke kișke? (4.5)

(Can you tell us what is the best place you have visited till now?) cihên taybet

B: her cihekê [eee] digel [lll eee] hevala ez çubêmê gelekê xoșe. u çi nînin, belê her (0.2) cihekê digel hevala bît yê xoșe.

(Any place which I visited with friends is very nice..There is no particular place but

any..place I visited with friends is nice.) 

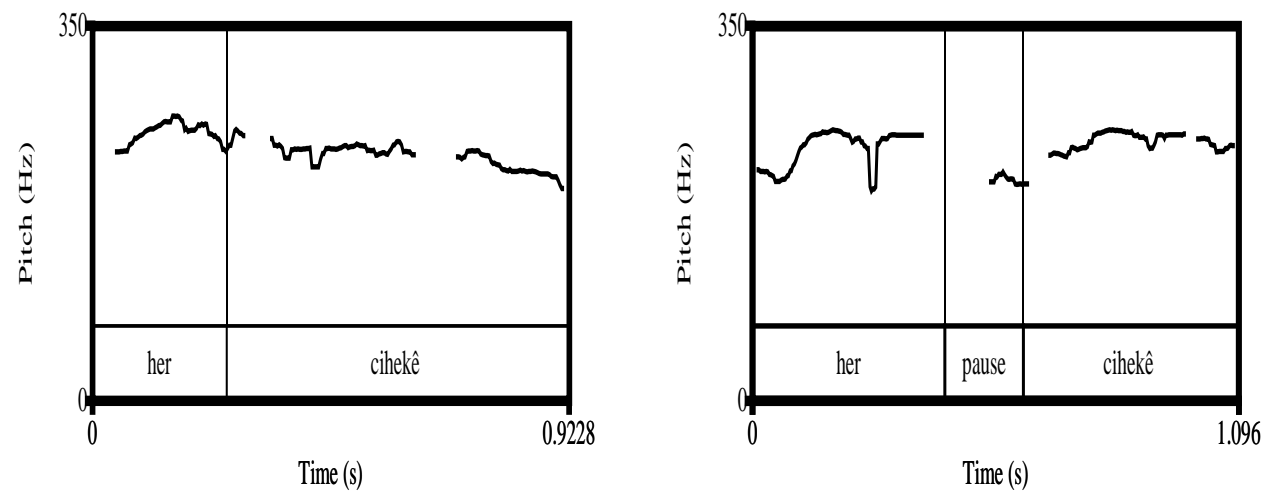

Figure 9: Duration comparison of $<$ her cihekê> and its repetition

The figure also illustrates that in the second repetition there is a difference in the duration of the words $<$ her $>$ and $<$ cihek $\hat{e}>$ : $<$ her $>$ is longer while $<$ ciheke $>$ is shorter.

To sum up, repetitions are usually shorter than their first mention. However, the repetition can be longer than the first to achieve some functions such as when the speaker wants to take some time to think about what to say next, in the case of hesitation, when the speaker wants to emphasise the repetition, the deletion and/or production of sound segments or it could be due to differences in the prominence structure of the utterances.

\section{Pitch contour and pitch range}

This section presents the differences in pitch contour and pitch range between the pairs of repetitions. Table 2 shows the comparison between the pitch contour of the first mention and its repetition.

Table 2: Differences in pitch contour of the repetition pairs

\begin{tabular}{|c|c|c|c|c|c|}
\hline & Utterance & $\begin{array}{l}\text { Pitch contour of the } \\
\text { first mention }\end{array}$ & $\begin{array}{r}\text { Pitch contour } \\
\text { repetitiol }\end{array}$ & $\begin{array}{l}\text { of the } \\
\text { n }\end{array}$ & $\begin{array}{l}\text { Pitch contour of the } \\
\text { third mention }\end{array}$ \\
\hline 1- & $\begin{array}{l}\text { di ḧeftiyêda (in } \\
\text { a week) }\end{array}$ & $\longrightarrow$ & $\sim$ & & \\
\hline $2-$ & $\begin{array}{c}\text { wekî tișt tu și çi } \\
\text { xerîbdbî } \\
\text { (As a thing, } \\
\text { what thing do } \\
\text { you miss?) }\end{array}$ & $-1<2$ & $\mu 1=$ & $\sim$ & \\
\hline 3- & $\begin{array}{l}\text { bi șevê (at } \\
\text { night) }\end{array}$ & $m$ & 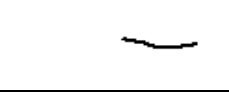 & & \\
\hline
\end{tabular}




\begin{tabular}{|c|c|c|c|}
\hline 4- & $\begin{array}{l}\text { ez ḧejê nakem } \\
\text { (I don’t like.) }\end{array}$ & ב- & $m \quad-2 \sim$ \\
\hline 5- & Nexêr (no) & & \\
\hline $6-$ & $\begin{array}{l}\text { zekeriya } \\
\text { e’bdula } \\
\text { (Zakeriya } \\
\text { Abdullah) }\end{array}$ & -- & $-\sim$ \\
\hline 7- & $\begin{array}{c}\text { deyka min (my } \\
\text { mother) }\end{array}$ & & $\sim$ \\
\hline 8- & $\begin{array}{c}\text { her cihekê (any } \\
\text { place) }\end{array}$ & & \\
\hline 9- & $\begin{array}{c}\text { parkên giștî } \\
\text { (general parks) }\end{array}$ & $\sqrt{n}$ & $\Gamma$ \\
\hline $10-$ & Zawîte (Zawite) & - מחב & r \\
\hline 11- & $\begin{array}{l}\text { eyub e'lî (Ayub } \\
\text { Ali) }\end{array}$ & & \\
\hline $12-$ & $\begin{array}{l}\text { bes korka (just } \\
\text { holes) }\end{array}$ & & r \\
\hline 13- & $\begin{array}{c}\text { em radkeyn } \\
\text { (we take them } \\
\text { away) }\end{array}$ & & \\
\hline $14-$ & $\begin{array}{c}\text { sebebê wê çiye } \\
\text { (what is the } \\
\text { reason behind } \\
\text { that) }\end{array}$ & & \\
\hline 15- & $\begin{array}{c}\text { zor supas bo te } \\
\text { (thank you very } \\
\text { much) }\end{array}$ & J & \\
\hline 16- & $\begin{array}{c}\text { me gazinde ser } \\
\text { h̆ukometê nîne } \\
\text { (we don't have } \\
\text { any complaints } \\
\text { againt the } \\
\text { government.) }\end{array}$ & 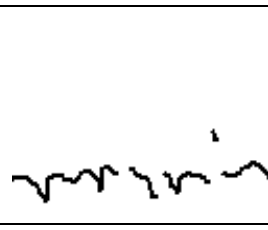 & \\
\hline
\end{tabular}




\begin{tabular}{|c|c|c|c|c|}
\hline $17-$ & $\begin{array}{l}\text { geștîyar } \\
\text { (tourist) }\end{array}$ & $\cdot-$ & S & \\
\hline 18- & $\begin{array}{c}\text { peșnîyarek ya } \\
\text { hey } \\
\text { (I have a } \\
\text { suggestion) }\end{array}$ & & - & \\
\hline 19- & $\begin{array}{l}\text { hizar silav } \\
\text { (thousands } \\
\text { regards) }\end{array}$ & & & \\
\hline $20-$ & $\begin{array}{c}\text { qonaxa avakirnê } \\
\text { (construction } \\
\text { stage) } \\
\end{array}$ & & & \\
\hline 21- & gelek (a lot) & & & \\
\hline $22-$ & $\begin{array}{c}\text { taybet eger } \\
\text { avîna ek layenî } \\
\text { bît (especially if } \\
\text { it is a one side } \\
\text { love) } \\
\end{array}$ & $\begin{array}{l}\iiint_{\substack{\text { overlap in the word } \\
<\text { taybet }>}} \\
\end{array}$ & & \\
\hline $23-$ & $\begin{array}{l}\text { ta șeva êk șembî } \\
\text { (till Sunday’s } \\
\text { night) }\end{array}$ & 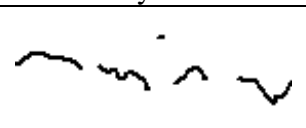 & $n$ & $-m$ \\
\hline $24-$ & $\begin{array}{l}\text { tu ji çi tirsiyay } \\
\text { (what were you } \\
\text { afraid of?) }\end{array}$ & $\sim \sim \sim$ & $\sim \neg \sim$ & \\
\hline $25-$ & $\begin{array}{l}\text { tu têda jiyaye } \\
\text { (did you live } \\
\text { in?) }\end{array}$ & r & & \\
\hline 26- & $\begin{array}{l}\text { em dê çîne } \\
\text { kurdistanê } \\
\text { (we will go to } \\
\text { Kurdistan) } \\
\end{array}$ & 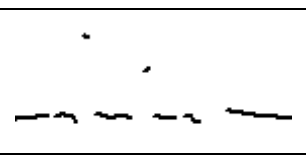 & m & \\
\hline 27- & $\begin{array}{l}\text { da li yarîgeha } \\
\text { xo ket } \\
\text { (they would } \\
\text { play in their } \\
\text { ground.) }\end{array}$ & 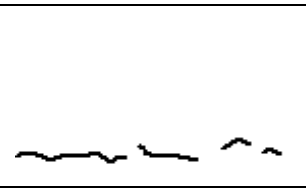 & 5 & \\
\hline
\end{tabular}

The table shows that there are less variation in the pitch contour of the repetitions. The repetitions have the same falling pitch contour except in the repetitions $\langle b i$ șevê $>$, <eyub e'lip and $<e m$ radkeyn $>$, it is found that there are differences in the pitch contour of the repetitions. In addition, no significant difference is observed in the pitch range of the repetition relative to the first mention of the utterance. This finding contradicts Curl, Local and Walker's (2006) finding that states that the pitch range of the repetition is typically compressed relative to the first mention of the utterance. 
The speaker repeated the phrase <bi șevê $>$ (at night) as an attempt to resay it in its ideal delivery. It is a kind of repair to the disruption that has occurred during his speech. So, he repeated $<b i$ șevê $>$ (at night) and completed it with <ez gohdarîya muzîkê $d k e m>$ (I listen to music.) as an ideal answer to the question being asked. Thus, he used the falling intonation in the first mention of $\langle b i$ șevê $>$ as the speaker includes this information to the participants' shared-knowledge, whereas the rising intonation on its repetition indicates that this information is to be interpreted with respect to the following information forming a larger unit that can be related to the discourse.

9- A: ee kengî tu gohdarîya muzîkê dkey? (0.6)

(When do you listen to music?)

B: eee (1) bara pitir ji (0.7) dema ez (0.3) bi șevê teqrîben ez (0.4) bi șevê ez gohdarîya muzîkê dkem.

(Mostly.. When I..at night approximately I...at night I listen to music.) In the repetition<eyub e'lî (Ayub Ali), the speaker repeats <eyub $e^{\prime} \hat{\imath}>$ because it seems that the interviewer is not familiar with the name given or she thinks that she misheared it so she asks again $\langle k \hat{\imath}>$ (who?) and the interviewee repeats the name again for clarification. The rising intonation is used in the first repetition because the speaker is giving a list, but the list is interrupted by the interviewer. According to Curl (2002), utterances like $<$ huh, what, hmm, what's that $>$ are known as next-turn repair initiators because they require their recipients to produce a repair in the next turn. We argue that the turn $<k \hat{\imath}>$ here is a next-turn repair initiators and the previous turn <eyub e'lis as a trouble source turn because it created some kind of problem to the interviewer and led to her production of $\langle k \hat{\imath}\rangle$. This trouble is repaired by the repetition of the trouble source turn.

10- A: bi nav u dengtirîn stranbêj li welatê te kîne dê șêy bêjye me? (0.4)

(Can you tell us who are the most famous singers in your country?)

B: zekerîya (0.4) (Zakerya)

A: zekerîya. (Zakerya)

B: eyub e’lî (0.8) (Ayub Ali)

A: kî? (Who?)

B: eyub e’lî (Ayub Ali.)

In <em radkeyn $>$ (We take them away.), the speaker is thinking about what to say next. In the first mention of <em radkeyn $>$ the speaker used rising pitch to indicate that he has not finished with what he is saying and he is to add more. Whereas the second is done with falling pitch to indicate that this is really what they do.

From what has been said above, it can be concluded that the repetitions have the same pitch contour as the first mentions and no significant differences in pitch range between them is observed. Some 
differences in pitch contour are observed which are used to do some communicative functions, for example the rise in the repetition instead of the falling in the first mention is used to indicate that this information is to be interpreted with respect to the following information, whereas the falling contour in the repetition instead of the rising in the first mention is used to indicate that the speaker is finished with what he is going to say.

\section{Loudness characteristics}

The repetitions are produced with a lower intensity than their first mention in the majority of the cases (except in 8 cases in which the repetitions have a higher intensity than their first mentions). The following table shows the differences in the loudness between the repetition pairs in decibel.

Table 3: Differences in pitch contour of the repetition pairs

\begin{tabular}{|c|c|c|c|c|}
\hline & Utterance & $\begin{array}{l}\text { loudness of the first } \\
\text { mention }\end{array}$ & loudness of the repetition & $\begin{array}{l}\text { loudness of the third } \\
\text { mention }\end{array}$ \\
\hline $1-$ & $\begin{array}{l}\text { di ḧeftiyêda } \\
\text { (in a week) }\end{array}$ & 58.12442724990059 & 57.120997826189075 & \\
\hline $2-$ & $\begin{array}{l}\text { wekî tișt tu și } \\
\text { çi xerîbdbî̀ } \\
\text { (As a thing, } \\
\text { what thing do } \\
\text { you miss) }\end{array}$ & 56.18936716886176 & 61.03905806150695 & \\
\hline 3- & $\begin{array}{l}\text { bi șevê (at } \\
\text { night) }\end{array}$ & 62.267396770769075 & 57.88975272789876 & \\
\hline $4-$ & $\begin{array}{l}\text { ez ḧejê nakem } \\
\text { (I don't like.) }\end{array}$ & 57.74258286883008 & 54.99488441092428 & \\
\hline 5- & Nexêr (no) & 49.824425340262444 & 49.52837700387335 & \\
\hline 6- & $\begin{array}{l}\text { zekeriya } \\
\text { e’bdula } \\
\text { (Zakeriya } \\
\text { Abdullah) }\end{array}$ & 62.28574228610125 & 62.148081965598124 & \\
\hline $7-$ & $\begin{array}{l}\text { deyka min } \\
\text { (my mother) }\end{array}$ & 61.8527078033152 & 60.55436226520556 & \\
\hline $8-$ & $\begin{array}{l}\text { her cihekê } \\
\text { (any place) }\end{array}$ & 68.37912715196966 & 63.96544288844983 & \\
\hline $9-$ & $\begin{array}{c}\text { parkên giștî } \\
\text { (general parks) }\end{array}$ & 59.06836970751919 & 54.29136574017376 & \\
\hline $10-$ & $\begin{array}{l}\text { Zawîte } \\
\text { (Zawite) }\end{array}$ & 55.116428860225994 & 55.203396139907454 & \\
\hline 11- & $\begin{array}{c}\text { eyub e'lî } \\
\text { (Ayub Ali) }\end{array}$ & 60.127795264091155 & 61.83523447993713 & \\
\hline $12-$ & $\begin{array}{l}\text { bes korka (just } \\
\text { holes) }\end{array}$ & 68.14745413945359 & 66.84352602893657 & \\
\hline 13- & $\begin{array}{l}\text { em radkeyn } \\
\text { (we take them } \\
\text { away) }\end{array}$ & 74.20165106785687 & 75.03764221807677 & \\
\hline $14-$ & $\begin{array}{l}\text { sebebê wê } \\
\text { çiye } \\
\text { (what is the } \\
\text { reason behind }\end{array}$ & 71.94665405270854 & 68.12886846674922 & \\
\hline
\end{tabular}




\begin{tabular}{|c|c|c|c|c|}
\hline & that) & & & \\
\hline 15- & $\begin{array}{c}\text { zor supas bo te } \\
\text { (thank you } \\
\text { very much) }\end{array}$ & 69.30954844883274 & 66.16107698245587 & \\
\hline 16- & $\begin{array}{c}\text { me gazinde ser } \\
\text { hukometê nîne } \\
\text { (we don't have } \\
\text { any } \\
\text { complaints } \\
\text { againt the } \\
\text { government.) }\end{array}$ & 75.82011604667451 & 75.36976240202434 & \\
\hline 17- & $\begin{array}{l}\text { geștîyar } \\
\text { (tourist) }\end{array}$ & 79.00757005267397 & 80.72204137993403 & \\
\hline 18- & $\begin{array}{c}\text { peșnîyarek ya } \\
\text { hey } \\
\text { (I have a } \\
\text { suggestion) }\end{array}$ & 68.90002577031731 & 75.58797051491486 & \\
\hline 19- & $\begin{array}{l}\text { hizar silav } \\
\text { (thousands } \\
\text { regards) }\end{array}$ & 73.08057761152556 & 71.17818673080546 & \\
\hline $20-$ & $\begin{array}{c}\text { qonaxa } \\
\text { avakirnê } \\
\text { (construction } \\
\text { stage) }\end{array}$ & 80.83326847792202 & 77.61492885395228 & \\
\hline 21- & gelek (a lot) & 73.83107888442835 & 70.56349856739969 & \\
\hline $22-$ & $\begin{array}{c}\text { taybet eger } \\
\text { avîna ek } \\
\text { layenî bît } \\
\text { (especially if it } \\
\text { is a one side } \\
\text { love) }\end{array}$ & 81.4041045704688 & 76.06376890279138 & \\
\hline 23- & $\begin{array}{c}\text { ta șeva êk } \\
\text { șembî } \\
\text { (till Sunday’s } \\
\text { night) } \\
\end{array}$ & 76.55329257811444 & 76.76422341512239 & 70.18572214798438 \\
\hline $24-$ & $\begin{array}{l}\text { tu ji çi tirsiyay } \\
\text { (what were } \\
\text { you afraid of?) }\end{array}$ & 78.21006889449973 & 72.76778737306327 & \\
\hline $25-$ & $\begin{array}{l}\text { tu têda jiyaye } \\
\text { (did you live } \\
\text { in?) }\end{array}$ & 79.5322083378025 & 76.55919604587548 & \\
\hline $26-$ & $\begin{array}{l}\text { em dê çîne } \\
\text { kurdistanê } \\
\text { (we will go to } \\
\text { Kurdistan) }\end{array}$ & 68.28493238079217 & 72.29581216397197 & \\
\hline $27-$ & $\begin{array}{l}\text { da li yarîgeha } \\
\text { xo ket } \\
\text { (they would } \\
\text { play in their } \\
\text { ground.) }\end{array}$ & 74.24943513853836 & 72.37259464723675 & \\
\hline
\end{tabular}

The repetitions have a higher intensity because of emphasis as in<wekî tiṣt tu și çi xerîbdbî̀, <zawîte>, < geștîyar>, < ta șeva êk șembî > and $<e m$ dê çîne kurdistanê $>$ or mishearing the first mention as in $<$ eyub 
e’lî̀, <peșnîyarek ya hey>. In <wekî tiṣt tu și çi xerîbdbî̀ (As a thing, what thing do you miss), the interviewer is repeating the sentence for the sake of emphasis and making sure that the listener has understood it clearly because it appears from his response that he did not understand it clearly.

11- A: wekî tiṣt tu și çi xerîbdbî. (0.5) (As a thing, what thing do you miss?)

B: belê (yes?)

A: tu wekî tiṣt tu și çi xerîbdbî. (1.8) (you as a thing, what thing do you miss?)

B: ez bxo? (myself)

A: belê (0.6) (yes)

B: eeeee (0.5) ye'nî ji bilî va. (0.5) (it means in addition to these.)

A: ji bilî kesa. wekî tișt tu și çi xerîbdbî?

(in addition to persons, as a thing what thing do you miss?)

[belê]

In <zawite> (Zawite), the speaker gave <zawite> as an answer to the question and was thinking about another place. Then he repeated the same place as the only answer he has for that question. The second mention is heard louder because it gives an emphasis and it is direct and definite.

12- A: bi hizra te xoṣtrîn cih bo burîna bihinvedana çine? Eger kesek ji dervey welatî hat u pisyara te bket. tu dê kîs cihî bo helbjêrî? (0.5)

(What are the best places to spend holidays? If a foreigner asked you which place you will choose for him?)

B: zawîte (1.6) zawîte. (Zawite.. Zawite)

In <geștîyar> (tourist), the speaker repeated the word <geștîyar > for emphasis after the hearer said yes that he understands it and added $<\operatorname{dev}>$ to it to be more precise.

13- B: kak ë̈med (0.4) geștîyar (0.4) (brother Ahmed..tourist)

A: belê. (yes)

B: dev geștîyar (0.2) ew hemi gava ew rîbarê avêye liwêrê (0.8) war pa çi qesîsek tiṣtek nehat biwari wa (0) bawerbike çend sala bçin di wêrêra u bhin hindî tu binî ava liwêrê

(near tourist..there is always a river of sewage water there.)

In <ta șeva êk șembî̀ (until Sunday’s night), the second repetition is done for the sake of emphasis and reminding the hearers. It is louder than the first mention.

14- A: ta șeva êk șembî jiberko șeveka dî em nahêyne di xizmeta heweda (0) karekê fer bo me drust boye (0) em neçarin ko nehêyne di xizmeta heweda (0) jiber hindê (hhh) ta șeva êk șembî herçende dê gelek pirya hewe key u henji dê lirya me ken (hhh) lê dêbijine hewe bi anehiya xode ta șeva êk șembî bhevra bkehin ta wî demî bi xer u xoṣiyandabin 
(Until Sunday's night because we are not coming to the program next night..for an urgent matter..we are obliged not to come to the program..therefore hhh until Sunday's night although we will miss you and you will miss us as well hhh we will tell you until meeting you again in Sunday's night. Till then have a nice time.)

In <em dê çîne kurdistanê> (we will go to Kurdistan), the speaker repeated <em dê çîne kurdistanê $>$ to give it more emphasis and adding more information to it. It is said louder than the first mention.

15- B: hindî televizon qenatê wan dbêjît (0) em dê çîne kurdistanê (0.4) u sê noqtan dê înîn u dê hêyn (1) u em hemîjî gut em dê çîne kurdistanê têr geryêyn (0.3) u sê noqtan dê digel xo înîn u dê hêyn (0.5)

(On the TV their channel says..we will go to Kurdistan..and we will bring back three points with us..and we all. They said we will go to Kurdistan for a tour..and will come back with three points.

A: belê (yes.)

In $<$ eyub e'li $>$ (Ayub Ali), the speaker repeats $<e y u b e^{\prime} l \hat{l}>$ because it seems that the interviewer is not familiar with the name given or she thinks that she misheard it so she asks again $<k \hat{\imath}>$ (who) and the interviewee repeats the name again for clarification. The second mention is produced louder so that the interviewer will hear it clearly.

In <peșnîyarek ya hey> (have a suggestion.), speaker B repeated $<$ peșnîyarek ya hey> thinking that the hearer, speaker A, did not hear it which he picked up from the rising intonation in his $<$ bele $>$ which the speaker A used asking him to continue. So he repeated in a louder voice.

16- B: dem baș bra çewanî bașî. (Hello brother. How are you?)

A: demê te baștir serçavêt min (0.6) (Hello, you welcome.)

B: seyda mejî peșnîyarek ya hey (0.3) (Sir we also have a suggestion.)

A: belê (yes)

B: me peșnîyarek ya hey (we have a suggestion.)

A: belê keremke (Yes please.)

This finding that the repetition is of lower intensity that the first mention of the utterance contradicts the finding of Curl, Local and Walker (2006) that the first and second parts of doubles are loudness integrated, with no notice-able increases or decreases in overall loudness from the first part to the second. Besides, as indicated the repetitions are heard louder than the first mentions for special purposes such as giving more emphasis or clarification of the misheard information.

\section{Prominence and phrasing}

As for phrasing, there is less variation between the first mention of the utterances and their repetitions, except in some few cases in which 
variation in phrasing is observed. For instance in $<$ her cihekê $>$ (any place), the repetition is produced as two intonational phrases $\langle$ her $>$ and $\langle$ ciheke $>$ because the speaker produced a pause after <her $>$. The aim is to give an emphasis to both parts. See figure (9) that shows the difference in phrasing in the first mention and the repetition of this utterance.

Regarding prominence, again there is less variation between the first mention and the repetition of the utterances, except in few cases in which some variation in prominence is observed. For example, in <sebebê wê çiye> (what is the reason behind it) the repetition is done for the sake of emphasis. In the first mention, there is accent on both <sebebê wê $>$ and $<$ çiye $>$ for the speaker would like to know the reason by accenting the question word. In the second mention, the main accent is on <sebebê wê emphasising that he wants the reason. Besides, there is a difference in phrasing for the first mention is produced as two intonational phrases whereas the repetition as one. Figure (10) shows the differences in phrasing and prominence of <sebebê wê çiye> and its repetition.

17- A: sebebê wê çiye ev șarie’ xiradbin. sebebê wê çiye? (0.6) bome wi sebebî bêjin.

(What is the reason behind the destruction of the streets? What is the reason behind it? Tell us that reason.)
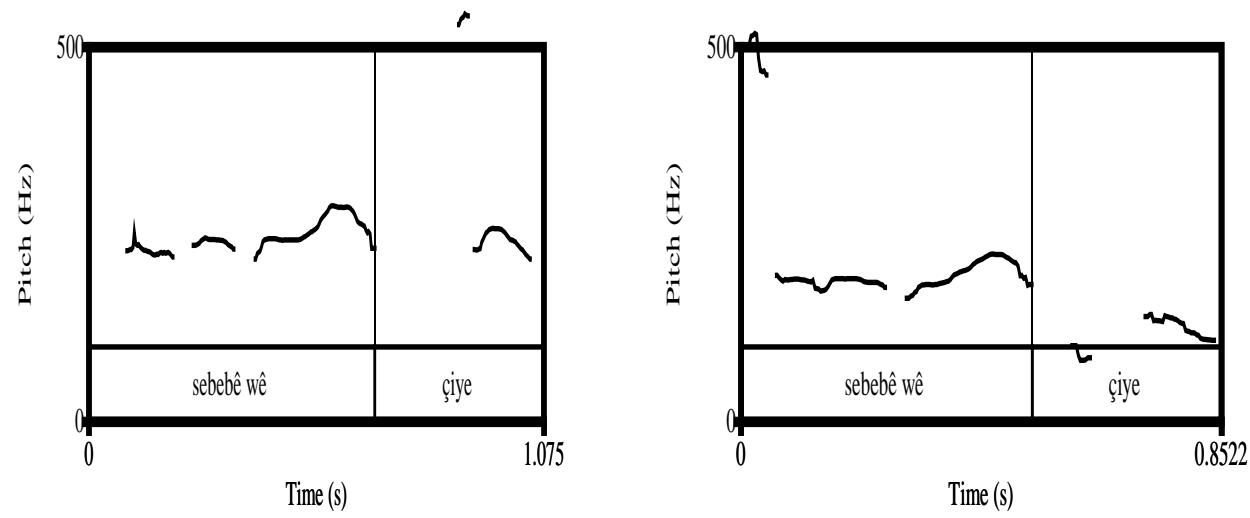

Figure 10: Differences in phrasing and prominence of the utterance $<$ sebebê wê çiye $>$ and its repetition

Another example that illustrates that there is difference in prominence between the first mention of an utterance and its repetition is found in <tu ji çi tirsiyay>. The speaker repeated the question for the sake of emphasis. In the first mention the main prominence is on the question word $<$ çi $>$ whereas in the repetition the prominence on the question word is 
reduced to a secondary one and the main prominence is placed on the word $<$ tirsiyay $>$ (see figure 7 above). The speaker wanted to highlight that word.

\section{Functions of repetitions}

It is observed that repetitions have different communicative functions used by the social interactants to meet their various interactional needs in conversation. This section will present the main functions observed in the data.

One of the obvious functions of repetitions in the data is that they are used a means by the speaker to think about what to say next. For instance, in:

18- A: dê șêy bêjiyeme [m] bi nîzîkîve rojê çend carat u gohdariya [m] myuzîkê dkey

(Can you tell us how many times do you listen to music approximately?)

B: di h̆eftiyêda (0.5) ez neșêm dest nîșan kem ka ez rojê çenca gohêxodemê bes [s] di roja ez

h̆eftiyêda (0.3) dṣêm bêjme te (0.5) di rojêt ḧeftiyêda (0.4) du roja sê

gohêxodemê. in a week..I

(In a week..I cannot specify how many times in a day I listen to it but

can say..in the days of the week..two or three times I listen to it.)

The speaker is delaying his speech because he has not yet formulated what he wants to say. In other words, the repetition is done for the speaker is thinking about what to say next.

Another function of repetitions is that they are used for clarification. For example, when the interactant does not understand what has been said in the previous turn, as in example 11. The speaker is repeating <wekî tiṣt tu și çi xerîbdbî $>$ because the listener has not understood the utterance clearly which is indicated by the use of the rising pitch on the words $\langle$ bele $\rangle$. So the repetition is done for the sake of clarification and this type of self-repeat is interrupted by a reactive turn from the listener.

The clarification function is also obvious when the social interactant does not catch up what the speaker says in the previous turn, as in example 10. The speaker repeats <eyub e'li $>$ because it seems that the interviewer is not familiar with the name given or she thinks that she misheared it so she asks again $<k \hat{\imath}>$ (who) and the interviewee repeats the name again for clarification.

Furthermore, repetitions have a clarification function also when an overlap occurs, as in: 
19- A: merh̆eba (0) demê hewe baṣ (0) çewanî bașî [bxêrhatina mêvanê teji dkem]

(Hello..have a nice time..how are you[we welcome your guest]

$\mathrm{B}$ :

[zor supas bo te]

(0.3) zor supas bo te.

(Thank you very much. Thank you very much)

The speaker second mention of <zor supas bo te> (Thank you very much) is a turn repair of her first turn which was overlapped with the other speaker speech. So she thinks that he might not heard it, that is why it is repeated.

A third function of repetitions is the emphasising function, i.e. the speaker wants to highlight or emphasise a word or a phrase in his conversation. For example, in:

20- A: ee kengî tu gohdarîya muzîkê dkey? (0.6) (When do you listen to music?)

B: eee (1) bara pitir ji (0.7) dema ez (0.3) bi șevê teqrîben ez (0.4) bi șevê ez gohdarîya muzîkê dkem.

(Mostly..when I..at night approximatelt I..at night I listen to music.)

The speaker repeated the phrase <bi șevê $>$ as an attempt to resay the phrase in its ideal delivery. It is a kind of repair to the disruption that has occurred during his speech. So he repeated $<b i$ șevê for emphasis and completed it with < ez gohdarîya muzîkê dkem> as an ideal answer to the question being asked.

A fourth function of repetitions is that they act as hesitation markers, as in:

21- B: silav bo te uu ...inșala (0.4) destêt we xoṣbin inșala hîn her serkeftîbin

(Greetings to you..God will..well done wish you success.)

A: zor supas saxbî fermu (1.06) (Thank you very much, please start.)

B: ejî live rojê hizar silav (0) hizar silav (0.6) li giyanê giyanê șehîd leyla qasim bin u (0.4) hemî șehîdin afret șehîdin bin u hemi șehîdin kurdistanê..

(Here I also give thousands regards.. thousand regards..to the soul of martyr Layla Qasim..and to the soul of all the female martyrs and martyrs of Kurdistan.)

The repetition is done for the sake of hesitation which is obvious from a number of repetitions and pauses he did.

To sum up, repetitions in talk in interaction perform different communicative functions. They are used for clarification when a misunderstanding, mishearing or overlap occur. Besides, they are used as a means by the speaker to have time to think about what to say next. 
Furthermore, they are used as hesitation markers and the most outstanding function is emphasis.

\section{Conclusion}

The study examined the phonetic features of repetitions in Kurdish. It aimed to analyse the phonetic features of repetitions and their functions in talk-in-interaction. The study concentrated on differences of some phonetic features such as duration, intensity, pitch contour, pitch range, prominence and phrasing. Less variation is observed between the first mentions of the utterances and their repetition concerning the features of pitch contour, pitch range, prominence and phrasing. Concerning duration, repetitions are usually shorter than their first mention except in some cases when the speaker wants to take some time to think about what to say next, in the case of hesitation, when the speaker wants to emphasise the repetition, the deletion and/or production of sound segments or it could be due to differences in the prominence structure of the utterances. As for intensity, the findings of the study revealed that the repetition is of lower intensity than that of the first mention of the utterance. For special purposes, the repetitions are produced louder than the first mentions such as giving more emphasis or clarification of the misheard information.

As for the functions, repetitions in talk in interaction perform different communicative functions. They are used for clarification when a misunderstanding, mishearing or overlap occur. Besides, they are used as a means by the speaker to have time to think about what to say next. Furthermore, they are used as hesitation markers and the most outstanding function is emphasis.

Thus repetitions are not only a marker of disfluent speech, but also a part of everyday social interaction and conversation used to perform special communicative functions.

\section{References:}

Bard, E. G., A. J. Lowe and T. M. Altmann (1989). The effect of repetition on words in recorded dictations. In First European Conference on Speech Communication and Technology. Paris, France. Available at http://www.isca-speech.org/archive.

Curl, T. S. (2002). The phonetics of sequence organisation: an investigation of lexical repetition in other-initiated repair sequences in American English. $\mathrm{PhD}$ thesis, University of Colorado.

Curl, T. S.; Local, J. and Walker, G. (2006). Repetition and the prosodypragmatics interface. Journal of pragmatics , Volume 38, Issue 10, Pages 1721-1751. 
Fowler, C. A. (1988). Differential shortening of repeated content words produced in various communicative contexts. Language and speech 31 (4) , 307-20.

Fowler, C. A. and Housum, J. (1987). Talkers signaling of 'new and old' words in speech and listeners' perception and use of the distinction. Journal of memory and language 26 , 489-504.

Hasan, A. M. (2012). Kurdish intonation with reference to English. Unpublished PhD thesis. University of Ulster, UK.

Hsieh, F. (2011). Repetition in social interaction: a case study on Mandarian conversations. In International Journal on Asian Language Processing, 19 (4), pp 153-168.

Laver, J. (1994). Principles of phonetics. Cambridge: Cambridge University Press.

Levinson, S. C. (1983). Pragmatics. Cambridge: Cambridge University Press.

Schegloff, E. A. (1996). Confirming allusions: towards an empirical account of action. American journal of sociology 102 (1), 161-216.

Sidnell, J. (2010). Conversation Analysis: An Introduction. Singapore: Wiley-Blackwell.

Tannen, D. (2007). Talking voices: Repetition, dialogue, and imagery in conversational discourse. Cambridge: Cambridge University Press.

Wong, J. (2000). Repetition in conversation: a look at 'first and second sayings'. Research on language and social interaction 33(4), 407-424.

Wooffitt, R. (2005). Conversation Analysis and Discourse Analysis. London, Thousand Oaks, New Delhi: Sage Publications. 